\title{
An extended VRIO model as a framework for sustainable tourism planning
}

\author{
J. Simão \\ CIEO - Research Center for Spatial and Organizational Dynamics, \\ Universidade Aberta, Portugal
}

\begin{abstract}
The management of resources by a tourism destination is of crucial importance for sustainable tourism development. The Resource-based View, a relevant school of strategic thought, offers a conceptual model for the analysis of organizational resources. This paper proposes to extend this model to the sustainability of tourist destinations. That is, assuming the VRIO model, and recognizing its usefulness as a tool for resource analysis, we introduce the sustainability dimension. The VRISO(S) model proposed here is intended as a starting point for discussion about the management of tourism resources in the context of sustainable development and competitive advantage to be undertaken by Destination Management Organizations.
\end{abstract}

Keywords: sustainable tourism, strategic management, Resource-based View, competitive advantage, VRIO model.

\section{Introduction}

Due to environmental and social pressures, a lot has been claimed for sustainable tourism development (s.t.d.). Both scientific literature and tourism organisations are unanimous as to the need for it. Nevertheless, it is not always easy to step forward towards implementation because, it must be acknowledged, it is less difficult to debate sustainability in theoretical terms than putting it into practice. Not that it is easy to debate sustainable tourism, but the fact is that it is even harder to put into practice or, as mentioned in the editorial of the first issue of the Journal of Sustainable Tourism, "(...) to walk the talk". In the tourism industry, the practice of sustainable development (s.d.) gains higher relevance and complexity due to the mix of products and services that integrate the industry 
and the wide spectrum of environmental and social-economical impacts it involves.

This amalgam of tourism products reveals a remarkable set of resources used to attract and satisfy the demand. Environmental and socio-economic resources are the main contributors to tourist attraction. Some of these resources are common to the entire community, easily degradable and depreciable and, upon depletion, are not reproducible. Therefore, it is easy to understand that the management of tourism resources is one of the main challenges ahead of the Destination Management Organizations (DMOs). Only a careful management of the tourism resources will allow a certain destination to promote sustainable development within the framework of strategic competitiveness. Yet, the most common is for these issues to be addressed separately. That is, on the one hand planning as a tool for analysis, action and vision for the future, aiming at providing tourism development that is sustainable for the tourism destination. At best, it is the most common planning perspective of the public institutions with responsibilities in the tourism industry. On the other hand, strategic planning is aimed at obtaining competitive advantages, and mainly promoted by the companies operating in the sector. This twofold approach towards the reasoning behind strategic planning is based on a deficient idea by the public and private planners. The first tend to forget the rivalry and competition between different touristic locations, regions and destinations. Companies assume very little compromise towards social responsibility. In fact, geographical locations compete with one another for a certain type of tourism and tourists, and this competitiveness must be approached and considered in the public planning model.

The Resource-based View (RBV) is a school of strategic management that provides pivotal importance to the internal resources of the organisation in order to obtain competitive advantages. This work intends to extend the VRIO model (a resources analysis model) to the sustainability of tourism destinations, thus contributing to a more integrated approach of strategic planning in tourism.

\section{Tourism planning}

Planning consists of an ordered sequence of operations and actions designed at organising and controlling tourism development in the areas of destination, according to the outlined political objectives $[1,2]$. Taking place under different forms (e.g. development, infrastructures, use of resources, marketing and promotion), institutions (different governmental organisations) and levels (national, regional, local) [3, 4], it aims at providing satisfaction to tourists, improving economic benefits and minimizing the negative impacts on the destinations [5-8]. In the absence of strategic planning, organisations tend to make decisions in an $a d$ hoc and reactive way [9].

Notwithstanding the works by Mintzberg [10-12] on the lower importance, and even the negative role, of strategic planning (and not of strategic thought) within the scope of companies, it seems evident that, in the fields of tourism and leisure, strategic planning has been conquering its place and "is here to stay" 
[13]. Even though he questions this character of permanence when arguing that the importance of planning is cyclic, Costa [14] detects clear signs for the revival of planning in this activity: "Even those who most strongly favour market-led approaches are already claiming more planning approaches in areas where deregulation was the rule in the 1980" (Ibidem:19).

The acknowledgement of public planning, as a tool to promote sustainable tourism development, is confirmed by several initiatives by international bodies. WTO has produced guides for local tourism planning; EU, on its turn, approved in 2001 the Strategy for Sustainable Development and, in 2007, the Agenda for a Sustainable and Competitive European Tourism, where due emphasis is provided to the need for strategic planning in tourism activity; and the United Nations point out the period 2005-2015 as the decade for the universal establishment of s.d. strategic character.

\section{RBV as a strategic management school}

Strategic management consists of analysis (of the mission, the vision, the strategic objectives, the internal and external environment), decisions (where and how competition will take place) and actions (that will lead to the implementation of the strategy) that an organisation carries out in order to create competitive advantages [15], and satisfy the stakeholders [16]. One of the keyissues in strategic management is to know: "why do some organisations perform better?" There is no single answer and it raises different readings. The theory of industrial organisation (I/O) states that competitive advantages are justified by external factors. RBV holds that what is determinant are the internal resources and competencies of the organisation, putting forward two distinctive assumptions concerning the $\mathrm{I} / \mathrm{O}$ perspective [17]:

- Organisations have a heterogeneity of resources that differentiate them from one another, and asymmetry exists regarding resource allocation;

- This heterogeneity may persist throughout time, and the transfer of resources between organisations is limited.

For RBV, the organisation is a unique bundle of resources and capabilities $[18,19]$, which combination develops core competencies, becoming a source of competitive advantages. Therefore, this does not derive from the market and industry structures (as supported by the I/O model) but of internal resources, enhanced when they are valuable, rare, imperfectly imitable, and adequately exploited by the organisation [20].

$\mathrm{RBV}$ and $\mathrm{I} / \mathrm{O}$ are two of the most influential schools of strategic thought as from the mid-twentieth century and, even though they build on different assumptions regarding the way competitive advantages are generated, many authors consider them not to be antagonistic but, rather, complementary approaches [21-26]. Studies show that both internal and external factors influence organisational performance and profitability throughout time [27, 28] and that organizations use both approaches in the strategic analysis stage [29, 30]. They are, in fact, methodologies included in the popular SWOT analysis. 


\section{Resources and tourism activity}

Amongst the different classifications of tourism resources that can be found in literature, the one put forward by Ritchie and Crouch [31] stands out. These authors have created a conceptual model, of an explanatory nature, for the strategic competitiveness of destinations, which is the most debated and detailed model on the competitiveness of tourism destinations within the scope of sustainability. The analysis of the (support and central) resources sets (almost entirely) the basis for the model which, building on Porter, differentiates between: human resources, physical resources, knowledge resources, capital resources, infrastructures, superstructures, and (tangible and intangible) historical and cultural resources. The key factors that attract visitors to a certain destination are named by the authors as core resources and attractors. This group includes physiography and climate, culture and history, and the tourism superstructure.

Similarly to companies, tourism destinations are, thus, also considered as a 'bundle of resources' [32], and their management is crucial to deal with the impacts and promote development [33].

As destinations are especially dependent on physical and historical-cultural resources to attract visitors, an additional problem comes about: their deterioration. Balance is particularly demanding in tourism activity, since the resources attract visitors and the higher their number, the higher the risk of degradation of the attractions. Briassoulis [34] analyses tourism resources at the light of the tragedy of the commons [35], to stress out that to some tourism resources:

- there is a possibility of degradation by exploitation of one or more users;

- the access to resources cannot be restricted or subject to exclusion of additional users.

As a result, tourism resources may suffer from overuse by individuals who are, simultaneously, not interested in investing to maintain or recover them, since they are not their property. These resources are, therefore, characterised by the impossibility of their use being subject to exclusion (access to the resource cannot be excluded) and by subtractivity (the use of such resource by someone reduces the availability of the resource to someone else). The deterioration of the physical resources and the loss of cultural identity are almost always irreversible, resulting in the diminishing of their value due to the lower capacity to foster the opportunities (i.e. the ability to attract tourists). This situation can be due to: (i) overuse of such resources; (ii) lack of investment and maintenance; (iii) absence of analysis of the impacts caused by the increase of other resources (accommodation facilities or mega-events), or other economic activities. Consequently, it is fundamental that physical and historical-cultural resources are managed in order to promote maintenance and non-degradation, and that the remaining resources will contribute to their sustainability. 


\section{$5 \quad$ RBV and tourism destinations}

The universality of the challenge regarding the management of resources suggests the application to tourism destinations of theories initially developed for corporate strategic management [36], and specifically the RBV [37]. In fact, RBV assumptions, namely heterogeneity and non-mobility of the resources, are particularly present at the level of tourism destinations.

There is heterogeneity of the resources, which distinguish the destinations from one another. For example, the Mount Everest and the Eiffel tower are two unique resources. As they are not reproducible, there cannot be a homogenisation of the destinations regarding these two resources. Several examples like these can be found amongst natural and cultural resources that are, we cannot forget, particularly effective in attracting visitors. Nevertheless, destinations also have homogeneous, or homogeneisable, resources, such as the international hotel chains with standardised offer (e.g. Íbis), but which are not the determinant resources in attracting tourists.

Heterogeneity can persist throughout time, i.e., resources mobility is not evident and, in some cases, it is even impossible. This is the case of the transfer of the above mentioned resources. Besides, imperfect mobility as a feature of tourism resources had already been put forward by Melián-González and GarcíaFalcón [37].

Thus, when transposing the VRIO analysis [20] to tourism destinations we find that a resource (or a capability) is valuable if it allows the destination to implement strategies that will improve its efficiency and effectiveness, exploiting opportunities and/or neutralising threats. When a destinationcontrolled resource is not valuable, it means that the strategy should not encompass the exploitation of such resource. If a tourism destination controls a valuable, but not rare, resource, it can be seen as a strength. Its exploitation leads to a situation of competitive parity. If a beach, for example, allows for the attraction of a type of tourism segmented according to the intentions of the local community, we may affirm that this resource explores opportunities (increasing the number of visitors of a certain type).

When tourism resources are not only valuable but also scarce, a competitive advantage exists. The resource will be scarce, or rare, if few destinations will have it. For example, the coastal area of the European arch of the Mediterranean makes part of a limited set of countries and regions sought after by many visitors from the other European countries (and beyond). This tourism amalgam which encompasses climate, beaches, hotels, support and culture services (amongst others) are a rare asset in the European context, in face of the offer existing up north. If a resource is valuable and rare, but not hard to imitate, its exploitation causes the organisation to obtain a temporary competitive advantage, which will last until the competitors will develop or acquire the necessary resources to implement the strategy. It is a strength and becomes a distinctive competency, until that moment in time.

A resource is imperfectly imitable (or expensive to copy) if the other organisations do not have the capacity to imitate it. In VRIO analysis, for the 
competitive advantage to be long-lasting it is necessary for the resource to be not only valuable and rare, but also difficult to imitate. It can be extremely expensive and hard for a competitor to copy the resource due to reasons connected to unique historical conditions, causal ambiguity, social complexity, and imperfect substitutability. This is particularly true concerning core resources, as defined by Ritchie and Crouch [31]. The difficulty of imitating historical-cultural resources lies in the accumulation of unique historical factors (see the case of Barcelona [38]), as well as in the social complexity of the destination (see the case of Cuba [39]). In addition, the physical resources and the climate characteristics are, by nature, of imperfect substitutability. And therefore, the 'inimitability' of a tourism resource (or of a mix of resources) can become the factor that offers a long-lasting competitive advantage to tourism destinations, even more so when these are, one cannot forget, the determinant resources of tourism demand.

Besides the resources having to gather the described conditions, the community as a whole (local inhabitants, political powers, industry and remaining stakeholders) must also have a forth capacity: it must be able to adequately exploit the potential of such resources. If the tourism destination will have valuable, rare and hard to imitate resources, but it does not possess the competencies to fully benefit from them, then some of the potential competitive advantages will eventually be lost. To answer the turbulence of the surrounding environment, the organisation must manage and develop the resources in an adequate and dynamic form, which involves protecting the existing resources; continuously improving them; and creating new resources [19, 21]. The organisation processes are considered as complementary resources, since they have a limited capacity to, isolatedly, generate competitive advantages. The fact that a destination disposes of a large quantity and variety of resources does not mean that it is more competitive than another with less resources. Competitiveness depends in large extent of the competencies to manage the existing resources.

\section{The VRIO(S) model - a proposal}

As shown, tourism destinations have some heterogeneous and asymmetrical resources, of difficult, when not entirely impossible, transfer, a characteristic which, depending on the resource, can perpetuate in time. Tourism destinations, while 'bundle of resources', are, therefore, very concrete and vivid examples of spaces where the RBV assumptions fully occur. Nevertheless, some of the tourism destinations resources also have two other features that distinguish them from the generality of those that are available to companies - non-exclusion and subtractivity -, making their analysis even more complex.

Thus, regarding tourism resources it is necessary to identify the following: which of them can be classified as commons; how can they all, with no exception, contribute for s.t.d.; and which are decisive to obtain competitive advantages at the destinations. In that sense, the integration of sustainability as a dimension of the VRIO model is a relevant contribution towards the analysis and management of tourism resources. When we speak about qualifying factors of 
long-lasting competitive advantage, it does not suffice to consider if the resource is valuable, rare and inimitable, but it is also important to assess its protection and non-degradation, at least for those with potential to become generators of competitive advantage. The adaptation of the VRIO model to tourism destinations involves the modification of the original set of questions, and introducing the dimension of sustainability (Table 1).

The question to be asked within the scope of sustainability consists in knowing if the exploitation of a certain tourism resource is being carried out in order to contribute towards the sustainable tourism development of the region or destination. For that purpose, it is necessary that the resource is adequately managed aiming at its quantitative and qualitative non-degradation, and without negative impacts on other resources. How should the resources be managed in order to ensure their own sustainability and that of the destinations where they are located, is something that cannot be answered in a straightforward and single manner. It will depend on the type of resource at stake, of the plans, of the will and competencies of the local community, of the cultural background, and of the level of local tourism development. Thus, sustainable competitive advantage (Table 2) is achieved if the core tourism resources of a destination will be valuable, rare, hard to imitate, and if the community disposes of competencies to manage them, and if it does so in a sustainable manner.

To sum up, tourism destinations must manage their resources ensuring environmental protection and the social development of the communities, within a competitive framework from which it cannot escape. RBV provides significant

Table 1: $\quad$ VRIO(S) questions.

\begin{tabular}{|c|c|c|}
\hline Dimensions & Original VRIO question & VRIO(S) question \\
\hline Value & $\begin{array}{l}\text { Do a firm's resources and } \\
\text { capabilities enable the firm to } \\
\text { respond to environmental threats } \\
\text { or opportunities? }\end{array}$ & $\begin{array}{l}\text { Do a destiny's resources and } \\
\text { capabilities enable the destiny to } \\
\text { respond to environmental threats } \\
\text { or opportunities? }\end{array}$ \\
\hline$\underline{\text { Rarity }}$ & $\begin{array}{l}\text { Is a resource currently controlled } \\
\text { by only a small number of } \\
\text { competing firms? }\end{array}$ & $\begin{array}{l}\text { Is a resource currently controlled } \\
\text { by only a small number of } \\
\text { competing destinies? }\end{array}$ \\
\hline Imitability & $\begin{array}{l}\text { Do firms without a resource face } \\
\text { a cost disadvantage in obtaining } \\
\text { or developing it? }\end{array}$ & $\begin{array}{l}\text { Do destinies without a resource } \\
\text { face a cost disadvantage in } \\
\text { obtaining or developing it? }\end{array}$ \\
\hline Organization & $\begin{array}{l}\text { Are a firm's other policies and } \\
\text { procedures organized to support } \\
\text { the exploitation of its valuable, } \\
\text { rare, and costly to imitate } \\
\text { resources? }\end{array}$ & $\begin{array}{l}\text { Does the community's other } \\
\text { policies and procedures } \\
\text { organized to support the } \\
\text { exploitation of its valuable, rare, } \\
\text { and costly to imitate resources? }\end{array}$ \\
\hline Sustainability & - & $\begin{array}{l}\text { The resource is exploited in a } \\
\text { way that contributes to the std? }\end{array}$ \\
\hline
\end{tabular}


Table 2: $\quad$ The VRIO(S) model (adapted from Barney and Clark [17:70]).

\begin{tabular}{|c|c|c|c|c|c|c|}
\hline \multicolumn{7}{|c|}{ Is a resource or capability... } \\
\hline Valuable? & Rare? & $\begin{array}{l}\text { Cost to } \\
\text { imitate? }\end{array}$ & $\begin{array}{l}\text { Exploited by } \\
\text { organization? }\end{array}$ & $\begin{array}{c}\text { Managed in a } \\
\text { sustainable } \\
\text { way? }\end{array}$ & $\begin{array}{c}\text { Competitive } \\
\text { and } \\
\text { sustainable } \\
\text { implications }\end{array}$ & \begin{tabular}{|c|} 
Economic \\
performance
\end{tabular} \\
\hline No & - & - & No & No & $\begin{array}{l}\text { Competitive } \\
\text { disadvantage }\end{array}$ & $\begin{array}{l}\text { Below } \\
\text { normal }\end{array}$ \\
\hline Yes & No & - & & & $\begin{array}{c}\text { Competitive } \\
\text { parity }\end{array}$ & Normal \\
\hline Yes & Yes & No & & & $\begin{array}{c}\text { Temporary } \\
\text { competitive } \\
\text { advantage }\end{array}$ & $\begin{array}{l}\text { Above } \\
\text { normal }\end{array}$ \\
\hline Yes & Yes & Yes & Yes & & $\begin{array}{l}\text { Long-term } \\
\text { competitive } \\
\text { advantage }\end{array}$ & $\begin{array}{l}\text { Above } \\
\text { normal }\end{array}$ \\
\hline & & & & Yes & $\begin{array}{c}\text { Sustainable } \\
\text { competitive } \\
\text { advantage }\end{array}$ & $\begin{array}{l}\text { Above } \\
\text { normal }\end{array}$ \\
\hline
\end{tabular}

instruments to study the resources in a form that integrates competitiveness and sustainability, providing a wider vision and management of the tourism destinations.

\section{Conclusion}

The importance of tourism destinations strategic planning is presently consensual in academia and international organizations. It is essential to retain that strategic planning must encompass an analysis of the tourism resources, so that they can be strategically and adequately managed towards sustainability and competitiveness.

Both the I/O model and the RBV approach were developed paying little attention to the implications of integrating environmentally sustainable business practices in corporate strategy [40]. This position was in line with the idea, dominant until not long ago, that the first duty of managers should be to maximise shareholders benefits, and environmental initiatives should limit to legal obligations [41].

In the absence of a model specifically designed for the analysis of tourism resources and competencies aiming at obtaining competitive advantages, this work tried to adapt the VRIO model to tourism destinations aiming at a 
sustainable tourism development. It is in this sense that the dimension of sustainability assumes pivotal importance, because all resources must be managed with this objective in mind. A VRIO(S) model was then proposed that will question if the resources at the disposal of the community and of the tourism destination are managed in a sustainable manner.

Finally, it is worth mentioning that it is possible that the challenge of globalisation (while emerging phenomenon based on economical, political, socio-cultural and technological processes) will put some of the features of the resources at stake (namely being rare and inimitable). This will force the review of the analysis leading to competitive advantages in tourism destinations. Within this scope, the globalisation of the industry, markets, technologies, media and political power, which in large extent escapes the control of destinations planners and managers, will have a significant role in the definition of public national and regional tourism policies [42], and in cultural homogenisation [43, 44]. These elements will have a growing impact at the level of tourism resources management.

\section{References}

[1] Mason, P., Tourism Impacts, Planning and Management, Elsevier: Oxford, 2003.

[2] Page, S.J., Tourism management: managing for change, $2^{\text {nd }}$. ed., Butterworth-Heinemann: Oxford, 2007.

[3] Hall, C.M., Tourism planning: policies, processes and relationships, Pearson Education: Harlow, 2000.

[4] Gunn, C.A. \& Var, T., Tourism planning: basics, concepts, cases. $4^{\text {th }}$. ed., Routledge: London, 2002.

[5] Gunn, C.A., Emergence of effective tourism planning and development. Tourism: the state of the art, ed. A.V. Seaton, Wiley: New York, 1994.

[6] Timothy, D.J., Cooperative tourism planning in a developing destination. Journal of Sustainable Tourism, 6(1), pp.52-68, 1998.

[7] Timothy, D.J., Participatory planning: a view of tourism in Indonesia. Annals of Tourism Research, 26(2), pp.371-391, 1999.

[8] WTO, Sustainable tourism development: guide for local planners, WTO: Madrid, 1993.

[9] Tribe, J., Strategy for tourism. The management of tourism, ed. L. Pender \& R. Sharpley, Sage: London, 2005.

[10] Mintzberg, H., The fall and rise of strategic planning, Harvard Business Review, January-February, pp.107-114, 1994a.

[11] Mintzberg, H., Rethinking strategic planning part I: pitfalls and fallacies, Long Range Planning, 27(3), pp.12-21, 1994 b.

[12] Mintzberg, H., Rethinking strategic planning part II: new roles for planners, Long Range Planning, 27(3), pp.22-30, 1994c.

[13] Veal, A.J., Leisure and tourism policy and planning, $2^{\text {nd }} \cdot$ ed, CAB International: Wallingford, 2002. 
[14] Costa, C., Towards the improvement of the efficiency and effectiveness of tourism planning and development at the regional level: planning organizations and networks. The case of Portugal. PhD Thesis, Department of Management Studies, University of Surrey: England, 1996.

[15] Dess, G.G., Lumpkin, G.T. \& Eisner, A.B., Strategic management: creating competitive advantages, $3^{\text {rd }}$. ed, McGraw-Hill: New York, 2007.

[16] Harrison, J.S. \& Enz, C.A., Hospitality strategic management: concepts and cases, Wiley: New York, 2005.

[17] Barney, J.B. \& Clark, D.N., Resource-based theory: creating and sustaining competitive advantage, Oxford University Press: Oxford, 2007.

[18] Peteraf, M.A., Research complementaries: a resource-based view of the resource allocation process model (and vice versa). From resource allocation to strategy, J.L. Bower \& C.G. Gilbert, Oxford University Press: Oxford, pp.409-426, 2005.

[19] Wernerfelt, B., A resource-based view of the firm, Strategic Management Journal, 5, pp.171-180, 1984.

[20] Barney, J., Firm resources and sustained competitive advantage, Journal of Management, 17(1), pp.99-120, 1991.

[21] Ambrosini, V., The Resource-based view of the firm. Advanced strategic management: a multi-perspective approach, ed. M. Jenkins, V. Ambrosini $\&$ N. Collier, $2^{\text {nd }}$. ed. Palgrave: London, 2007.

[22] Foss, N.J., Research in strategy, economics, and Michael Porter. Journal of Management Studies, 33(1), pp.1-24, 1996.

[23] Henderson, R. \& Mitchell, W., The interactions of organizational and competitive influences on strategy and performance, Strategic Management Journal, 18 (special issue), pp.5-14, 1997.

[24] Hitt, M.A, Ireland, R.D. \& Hoskisson, R.E. (2007) Strategic management: competitiveness and globalization (concepts), $7^{\text {th }}$. ed, South-Western Cengage Learning: Mason, 2007.

[25] Lee, C. \& King, B., Assessing destination competitiveness: an application to the Hot Springs tourism sector, Tourism and Hospitality Planning \& Development, 3(3), pp. 179-197, 2006.

[26] Oliver, C., Sustainable competitive advantage: combining institutional and resource-based views, Strategic Management Journal, 18, pp.697-713, 1997.

[27] Hawawini, G., Subramanian, V. \& Verdin, P., Is performance driven by industry- or firm-specific factors? A new look at the evidence, Strategic Management Journal, 24, pp.1-16, 2003.

[28] McGahan, A.M., Competition, strategy and business performance, California Management Review, 41(3), pp.74-101, 1999.

[29] Douglas, T.J. \& Ryman, J.A., Understanding competitive advantage in the general hospital industry: evaluating strategic competences, Strategic Management Journal, 24, pp.333-347, 2003.

[30] Makhija, M., Comparing the resource-based and market-based views of the firm: empirical evidence from Czech privatization, Strategic Management Journal, 24, pp.433-451, 2003. 
[31] Ritchie, J.R.B. \& Crouch, G.I., The competitive destination: a sustainable tourism perspective, CAB International: Wallingford, 2003.

[32] Ryan, C., Equity, management, power sharing and sustainability - issues of the 'new tourism'. Tourism Management, 23, 17-26, 2002.

[33] Telfer, D.J. \& Hashimoto, A., Resource management: social, cultural, physical environment and the optimization of impacts. Tourism management dynamics: trends management and tools, ed. D. Buhalis \& C. Costa, Butterworth-Heinemann: Oxford, 2006.

[34] Briassoulis, H., Sustainable tourism and the question of the commons. Annals of Tourism Research, 29(4), pp.1065-1085, 2002.

[35] Hardin, G., The Tragedy of the Commons. Science 162, pp.1243-1248, 1968.

[36] Flagestad, A. \& Hope, C.A., Strategic success in winter sports destinations: a sustainable value creation perspective, Tourism Management, 22, pp.445461, 2001.

[37] Melián-González, A. \& García-Falcón, J.M., Competitive potential of tourism in destinations, Annals of Tourism Research, 30(3), pp.720-740, 2003.

[38] Rubio, S.P., La ciudad fingida. Representaciones y memorias de la Barcelona turística. Revista de Turismo y Património Cultural, 4(1), pp.1328, 2006.

[39] Sanchez, P.M. \& Adams, K.M. (2008) The Janus-faced character of tourism in Cuba. Annals of Tourism Research, 35(1), pp.27-46, 2008.

[40] Hart, S.L., A natural-resource-based view of the firm, Academy of Management Review, 20(4), pp.986-1014, 1995.

[41] Fowler, S.J. \& Hope, C., Incorporating sustainable business practices into company strategy, Business Strategy and the Environment, 16, pp.26-38, 2007.

[42] Fayos-Solà, E. \& Bueno, A.P., Globalization, national tourism policy and international organizations. Tourism in the age of globalization. S. Wehab \& C. Cooper, Routledge: London, 2001.

[43] Burns, P., Brief encounters: culture, tourism and the local-global nexus. Tourism in the age of globalization. S. Wehab \& C. Cooper., Routledge: London, 2001.

[44] Knowles, T., Diamantis, D. \& El-Mourhabi, J.B., The globalization of tourism \& hospitality: a strategic perspective. $2^{\text {nd }}$. ed. Thomson Learning: London, 2004. 